\title{
Kaolin-based Foliar Reflectant Affects Physiology and Incidence of Beet Curly Top Virus but not Yield of Chile Pepper
}

\author{
Rebecca Creamer, ${ }^{1}$ Soumaila Sanogo, Osama A. El-Sebai, \\ Jared Carpenter, Robert Sanderson \\ Department of Entomology, Plant Pathology, and Weed Science, New Mexico \\ State University, Las Cruces, NM 88003
}

Additional index words. Capsicum annuum, beet leafhopper, hyperspectral reflectance, Surround WP

\begin{abstract}
Kaolin reflectant treatments have been shown to reduce stress due to the environment, pests, and pathogens in many plants. We tested the effect of kaolin on yield, beet curly top virus (BCTV) incidence, and physiological parameters (measured as hyperspectral reflectance) of field-grown chile pepper (Capsicum annuum L.) in southern New Mexico. Curly top incidence was significantly lower in kaolin-treated chile blocks than untreated blocks. Peppers treated with the kaolin-reflectant showed significantly less water stress and higher photochemical reflectance than untreated plants during active growth periods. Treated plants had significantly higher levels of chlorophyll a and higher reflectance than untreated plants. Yield from treated plants was not significantly different from that from untreated plants. We did not detect any deleterious effects on peppers due to application of kaolin. Kaolin treatments suppressed beet curly top virus on chile and reduced water stress parameters during the hottest months of the growing season, suggesting that it would be useful in New Mexico chile production in years with moderate disease pressure.
\end{abstract}

Chile pepper (Capsicum annuum L.) production in the southwestern U.S. is limited by problems from the environment, diseases, and pests. Environmental constraints such as water stress, high solar irradiance, and soil moisture fluctuations are common in the arid and semi-arid chile producing areas of the southwestern U.S. Exposure to these various stresses influences physiological processes such as photosynthesis, and transpiration, which in turn affects plant growth and yield.

One significant pest problem for chile peppers in New Mexico is beet curly top virus (BCTV), a curtovirus, which is transmitted by the beet leafhopper Circulifer tenellus (Baker). BCTV infects a broad range of hosts that includes other crops and weeds from many plant families (Bennett, 1971). Disease symptoms on chile include severe stunting and chlorosis and death of young plants. BCTV-infected plants produce eitherno fruit or highly misshapen fruit, resulting in no marketable yield. High temperatures, low humidity, and high light intensity increase the severity and the rate of development of curly top disease in plants (Douglass and Cook, 1952).

Chile is not a primary host for the leafhopper, and the insect does not carry out its life cycle on the plant, but the vector can still efficiently transmit the virus to the plant with feeding

Received for publication 28 Oct. 2004. Accepted for publication 20 Nov. 2004. We thank Robin Matson of Engelhard for providing Surround WP, Jaime Rascon, Erik Oldrup, and Jarren Ray for help with spraying and harvesting trials. We also thank the New Mexico Chile Commission, the New Mexico Chile Task Force, and the New Mexico State University Agricultural Experiment Station for their support of this work.

'E-mail creamer@taipan.nmsu.edu. times as short as $15 \mathrm{~min}$ (Bennett, 1971). The leafhopper vector prefers arid to semi-arid conditions, bright sunny areas, and stressed plants; conditions that are frequently found in the southwestern U.S. (Douglass and Cook, 1952). Since $C$. tenellus is less likely to enter a shaded closed plant canopy, young plants are more susceptible to curly top than older plants (Romney 1943). Unfortunately, no effective measures are available to control curly top or the leafhopper vector on chile.

Reducing plant stress is important in ensuring optimum crop growth, yield, and quality. Studies conducted on a variety of crops including soybean, dryland cotton, artichoke, melons, and peach have shown that foliar applications of white kaolin mineral reduce leaf and fruit tissue temperature, and plant transpiration and water use, as a result of increased foliage reflection of infrared radiation(Baradas etal., 1976; Basnizki and Evenari, 1975; Glenn et al., 1999, 2002; Jifon and Syvertsen, 2003; Lipton and Matoba, 1971; Moreshet et al., 1979). In addition, leaf coating with white kaolin mineral reduces foliar diseases (Frederiksen, 1986; Glenn et al., 1999; Kamp, 1985; Schon, 1993; Ziv and Han, 1990) and suppresses insect pests including vectors of plant viruses (Cottrell et al., 2002; Liang and Lui, 2002; Marco, 1993; Puterka, et al., 2000; Showler 2002).

The objective of this work was to evaluate the ability of a kaolin-based foliar reflectant to improve yield, reduce plant stress, and reduce beet curly top virus incidence in chile.

\section{Materials and Methods}

This study was conducted during 2002 and
2003 at New Mexico State University's Leyendecker Plant Research Station at Las Cruces. Seed of chile pepper (Capsicum annuum 'B18') was planted in plots on $106 \mathrm{~cm}$ beds in midApril 2002 and in early April 2003. In 2002, mefenoxam $\left(175.4 \mathrm{~mL} \cdot \mathrm{ha}^{-1}\right)$, and carbofuran $\left(2.3 \mathrm{~L} \cdot \mathrm{ha}^{-1}\right)$ were applied at planting. Seedlings were thinned to 25.5 to $30.5 \mathrm{~cm}$ spacing. No fungicide or insecticides were used in the 2003 trials. During both years, plants were furrow irrigated at 7- to 14-d intervals.

There were two treatments for this work, kaolin-treated and untreated. Beginning at the six- to eight-leaf stage, plants were treated with a 3\% kaolin suspension (Surround WP, Engelhard, Iselin, N.J.) until thoroughly wetted using hand-held pump action sprayers that were constantly agitated. Plants were treated from late May through early July for a total of four applications in 2002, and from June through early September for a total of nine applications in 2003. Plants were treated at about 10 -d intervals. Kaolin treatments began at the same plant size, but on different dates in 2002 and 2003 due to differences in plant growth rates during the 2 years. Treatments were terminated earlier in 2002 than 2003 because of the frequent rains in July and August 2002, which washed the kaolin from the plants. Treatments were arranged in a randomized complete block design with four replications in 2002 and three replications in 2003. Plots were $100 \mathrm{~m}$ in length and 8 rows in width in 2002, and $300 \mathrm{~m}$ in length and 24 rows in width in 2003.

During 2003, chile single leaf reflectance over the wavelength range 350 to $2500 \mathrm{~nm}$ was measured for treated and untreated plants using a spectroradiometer (FieldSpec Pro; Analytical Spectral Devices ASD, Boulder, Colo.). Individual leaves were scanned on the upper (adaxial) surface using an external integrating sphere (1800-12; LI-COR, Lincoln, Neb.) specifically designed for measurement of leaf surface reflectance and transmittance. The integrating sphere was connected to the spectroradiometer by a fiberoptic cable.

Leaf reflectance was measured from two randomly chosen plants per plots at three height levels of the chile plant (upper, middle, and lower), one leaf per height level. Fifty readings were taken for each single leaf and averaged to reduce noise. Leaves from treated leaves were cleaned and the white particles were removed by gently rubbing with a cotton pad before scanning. Leaf reflectance was measured on two randomly chosen plants from each treated and untreated plots. Hyperspectral measurements (those made from 350 to $2500 \mathrm{~nm}$ ) were recorded weekly from early July until harvest. The spectra were stored on a hard disk for subsequent viewing and data analysis using ASD ViewSpecPpro version 4.2 software.

The collected hyperspectral data was used to calculate several vegetation physiological parameters such as water stress, chlorophyll content, photosynthesis, and nitrogen content. These parameters were used to assess differences in the spectral properties between the treated and untreated chile plants. Moisture stress index (MSI) was calculated as the ratio between reflectance $(\mathrm{R})$ at $1600 \mathrm{~nm}$ and reflectance $(\mathrm{R})$ 
Table 1. Effect of kaolin treatments on yield of chile.

\begin{tabular}{lccccc}
\hline & \multicolumn{2}{c}{$\begin{array}{c}\text { Avg total yield } \\
(\mathrm{kg} \pm \mathrm{SE})\end{array}$} & & & \multicolumn{2}{c}{$\begin{array}{c}\text { Avg marketable yield } \\
(\mathrm{kg} \pm \mathrm{SE})\end{array}$} \\
\cline { 2 - 3 } Treatment & 2002 & 2003 & & 2002 & 2003 \\
\hline Kaolin treated & $3.94 \pm 0.27$ & $4.15 \pm 0.98$ & & $2.10 \pm 0.26$ & $3.28 \pm 0.83$ \\
Untreated & $3.26 \pm 0.71$ & $3.77 \pm 0.94$ & & $2.30 \pm 0.5$ & $3.02 \pm 0.76$ \\
\hline
\end{tabular}

Table 2. Effect of kaolin treatments on moisture stress, photochemical reflectance, and Beet curly top virus $(\mathrm{BCTV})$ incidence in 2003; $\mathrm{MSI}=$ moisture stress index, $\mathrm{WBI}=$ water band index, $\mathrm{PRI}=$ photochemical reflectance index.

\begin{tabular}{lcccc}
\hline & & & PRI \pm SE \\
Treatment & $(1600 / 820 \mathrm{~nm})$ & $(900 / 970 \mathrm{~nm})$ & $(531+570 \mathrm{~nm})$ & $\begin{array}{c}\text { Mean BCTV incidence } \\
(\text { no. infected plants } \pm \mathrm{SE})\end{array}$ \\
\hline Kaolin treated & $0.525 \pm 0.011 \mathrm{a}^{\mathrm{z}}$ & $1.049 \pm 0.002 \mathrm{a}$ & $0.14 \pm 0.001 \mathrm{a}$ & $143 \pm 23.2 \mathrm{a}$ \\
Untreated & $0.542 \pm 0.014 \mathrm{~b}$ & $1.045 \pm 0.002 \mathrm{~b}$ & $0.009 \pm 0.001 \mathrm{~b}$ & $171 \pm 26.7 \mathrm{~b}$ \\
$P$ value & 0.013 & 0.015 & 0.003 & 0.015 \\
\hline
\end{tabular}

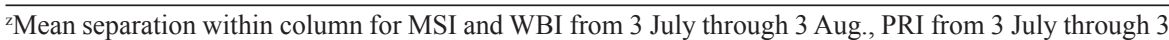
Sept. Means within columns followed by the same letter are not significantly different.

measured at $820 \mathrm{~nm}$ (Hunt and Rock, 1989). Water band index (WBI), which is correlated with the plant water content, was calculated as the ratio between reflectance at $900 \mathrm{~nm}$ and reflectance value measured at $970 \mathrm{~nm}$ (Gamon and Qiu, 1999; Penuelas et al., 1997a).

Chlorophyll-based difference index or Chlorophyll normalized difference index (Chl NDI) was calculated as $\left(\mathrm{R}_{750}-\mathrm{R}_{705}\right) /\left(\mathrm{R}_{750}+\right.$ $\mathrm{R}_{705}$ ) (Datt, 1998; Gitelson and Merzlyak, 1994; Gitelson et al., 1996). The chlorophyll-a concentration (RARS-a) was calculated using the reflectance ratio $\left(\mathrm{R}_{675} / \mathrm{R}_{700}\right)$, while the
Chlorophyll-b concentration (RARS-b) was calculated using $\left[\left(\mathrm{R}_{675} / \mathrm{R}_{650}\right) \times \mathrm{R}_{700}\right]$ (Datt, 1998). The photochemical reflectance index (PRI) was calculated as $\left(\mathrm{R}_{531}-\mathrm{R}_{570}\right) /\left(\mathrm{R}_{531}+\mathrm{R}_{570}\right)$ (Gamon et al., 1990; Penuelas et al., 1997b). Nitrogen index was calculated as $\left(\mathrm{R}_{800}-\mathrm{R}_{600}\right) /\left(\mathrm{R}_{800}+\right.$ $R_{600}$ ) (Ma et al., 1996). The red-edge, which shows the vitality of the plant, was calculated by the ratio of reflectance at 750 and $700 \mathrm{~nm}$, (Gitelson and Merzlyak, 1996).

Chile pods were harvested on 24 Sept. 2002, and 25 Sept. 2003. Within each plot, four sampling areas were arbitrarily selected for assessing chile yield. Each sampling area consisted of five adjacent plants without curly top symptoms. All pods from the five plants were hand-harvested and weighed, and designated as total yield. The harvested pods were then screened to exclude all nonmarketable pods. Pods were considered nonmarketable if theywerenoticeablyblemished from factors such as sunburn, blossom-end rot, or fungal disease. The remaining pods were weighed, and the resulting weight was designated as marketable yield. The average total yield and average marketable yield were computed from the four sampling areas within a plot.

Curly top incidence was assessed in each plot by counting the number of plants showing virus symptoms out of about 600 plants. Only plants taller than $25 \mathrm{~cm}$ were included because we wanted to assess curly top incidence that occurred after the kaolin treatments were initiated. The plants were about $25 \mathrm{~cm}$ height at the first kaolin treatment, and since infected plants stop increasing in height, and virus-infected plants $<25 \mathrm{~cm}$ would have been inoculated before the onset of the kaolin treatments; only those taller than $25 \mathrm{~cm}$ would have been inoculated after the onset of treatments. Symptoms used for assessment of virus infection included chlorosis, stunting, and stiff plant architecture. BCTV infection was confirmed in selected samples by PCR analysis (Creamer et al., 2003).

ANOVA procedures for a randomized complete block design were used to test for
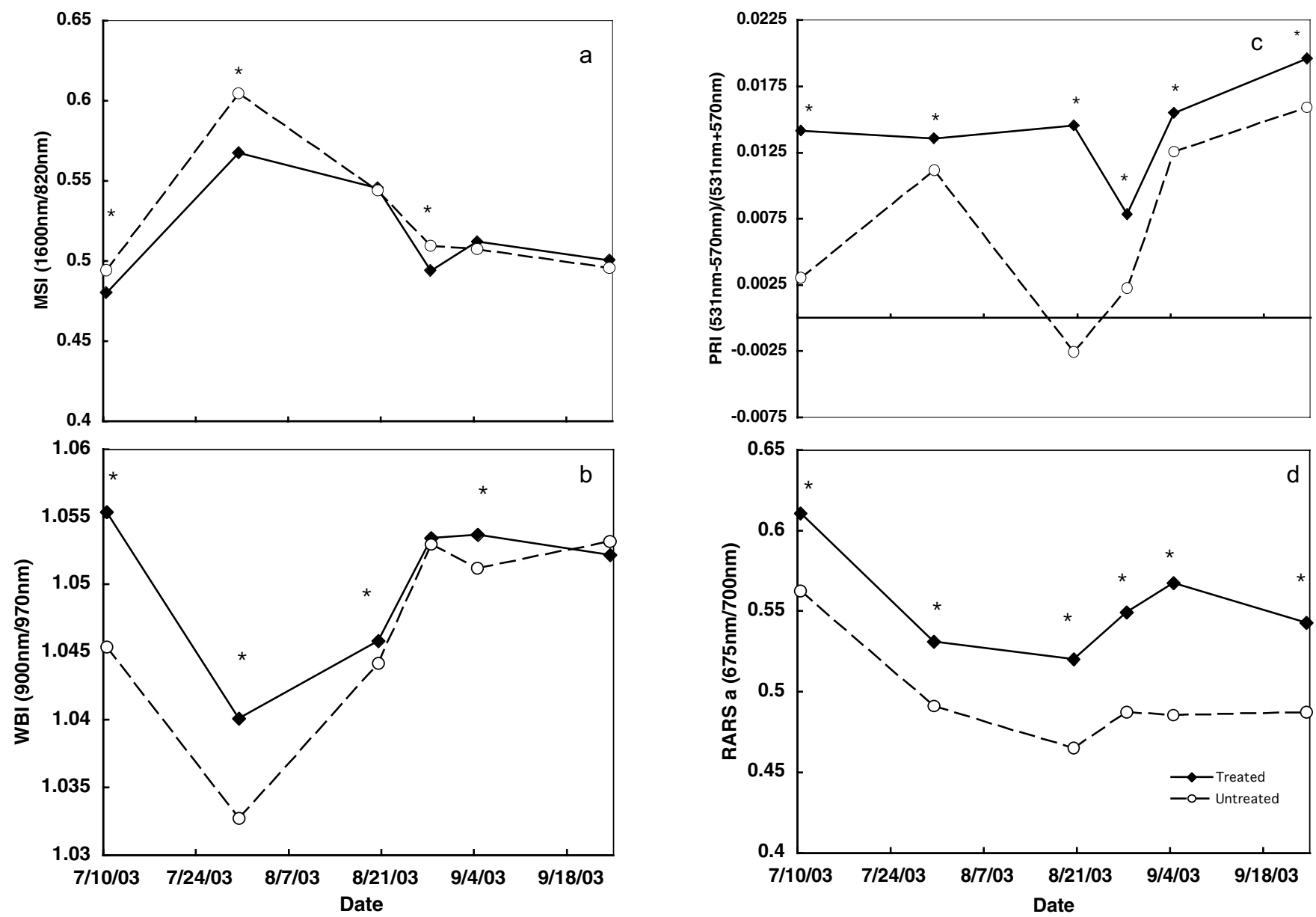

Fig. 1. Moisture stress index (MSI) (a), water band index (WBI) (b), photochemical reflectance index (PRI) (c), and chlorophyll a (RARS a) (d) of kaolin-treated and untreated chile in 2003. "Significant differences between treatments $\alpha=0.05$. 
Table 3. Effect of kaolin treatments on chlorophyll and nitrogen stress in 2003; RARS-a = chlorophyll-a, RARS-b $=$ chlorophyll-b, CBDI = chlorophyll based difference index..

\begin{tabular}{|c|c|c|c|c|}
\hline Treatment & $\begin{array}{l}\text { RARS-a } \pm \text { SE } \\
(675 / 700 \mathrm{~nm})\end{array}$ & $\begin{array}{l}\text { RARS-b } \pm \text { SE } \\
(675 / 650 \mathrm{~nm}) \\
\times(700 \mathrm{~nm})\end{array}$ & $\begin{array}{c}\mathrm{CBDI} \pm \mathrm{SE} \\
(750-705 \mathrm{~nm}) / \\
(750+705 \mathrm{~nm})\end{array}$ & $\begin{array}{c}\text { Nitrogen index } \pm \text { SE } \\
(800-600 \mathrm{~nm}) / \\
(800+600 \mathrm{~nm})\end{array}$ \\
\hline Kaolin treate & $0.552 \pm 0.010 \mathrm{a}^{\mathrm{z}}$ & $0.169 \pm 0.011 \mathrm{a}$ & $0.485 \pm 0.024 \mathrm{a}$ & $0.711 \pm 0.018 \mathrm{a}$ \\
\hline $\begin{array}{l}\text { Untreated } \\
P \text { value }\end{array}$ & $\begin{array}{c}0.488 \pm 0.008 b \\
0.0001\end{array}$ & $0.167 \pm 0.010 \mathrm{a}$ & $0.476 \pm 0.022 \mathrm{a}$ & $0.719 \pm 0.023 \mathrm{a}$ \\
\hline
\end{tabular}

${ }^{2}$ Means within columns followed by the same letter are not significantly different.

experimental factors (block and treatment). Treatment differences in yield, curly top virus infection, and physiological variables were gauged at a $5 \%$ significance level.

\section{Results and Discussion}

In both years of the experiment, kaolin treatments did not visibly harm chile. Average total yield and average marketable yield in kaolintreated plants were not statistically different $(P$ $>0.4$ ) from untreated plants in 2002 and 2003 (Table 1). While yield was not significantly improved in treated plants, yield taken was only from plants without BCTV-infection. Likely total yield from all plants in a treatment would have been significantly better in treated blocks compared to untreated, since curly top infected plants produce no marketable pods, leading to complete yield loss in infected plants. Thus, yield would be higher in treated blocks if all plants were harvested.

In 2003, the average incidence of beet curly top virus in the chile test field was $26 \%$. The average number of beet curly top virus-infected plants per sprayed block was 143 , which was significantly different $(P=0.015)$ from the average number of infected plants per untreated block, 171 (Table 2). The trials in 2002 showed no difference in curly top incidence in kaolintreated chile compared to untreated, and the field incidence of disease was very low $(<0.5 \%)$.

These results suggest that kaolin treatment can significantly reduce curly top incidence in chile seasons with moderate virus incidence (26\% in 2003). This level of virus infection was higher than levels in $2002(0.5 \%$ to $1 \%)$, but lower than average field infection levels compared to 2001 (30\% to 50\%) (Creamer et al., 2003). It is not surprising that the 2002 results showed no difference in curly top incidence in kaolin-treated chile compared to untreated, given the very low incidence of virus in the field.

The spectral analysis showed that the mean water band index (WBI), which is indicative of plant water content, was significantly $(P=$ $0.015)$ higher in treated plants than untreated plants during July and August sampling dates (Table 2, Fig. 1). Similarly, the moisture stress index (MSI) mean values increased during this high temperature period (Table 2, Fig. 1). MSI mean values significantly $(P=0.013)$ differed between treated and untreated plants during July and August. The lowest value for WBI and highest for MIS were recorded on 29 July in the untreated plants. Similar findings were reported by Jifon and Syvertsen (2003) who found that physiological effects of kaolin applications on grapefruit trees were most prominent midday on warm sunny days.
We found significant differences in the photochemical reflectance index (PRI) between the overall means of treated and untreated plants $(P=0.003)$ (Table 2, Fig. 1). Chlorophyll a was also significantly $(P=0.0001)$ higher in treated than untreated plants as measured by the chlorophyll-a index (RARS-a) (Table 3, Fig. 1). Kaolin was also shown to increase the chlorophyll ratio and leaf area for beans (Tworkoski et al., 2002).

Indices of chlorophyll-b (RARS-b), total chlorophyll (CBDI), nitrogen index, (Table 3 ), and red edge (data not shown) were not substantially affected by application of particle film. No significant differences were found in the overall means between treated and untreated chile plants for the four indices at all sampling dates.

Kaolin treatments provided suppression of beet curly top virus on chile and reduced water stress parameters during the hottest months of the growing season. These treatments were not begun until after virus had already entered the field. Early season kaolin treatments would likely decrease virus infection by suppressing the leafhopper vector, but not improve the water status of the plant since the weather would be cooler. Applications of kaolin at the onset of hot temperatures in New Mexico, which usually occurs in late May to early June, might help plants from being subjected to severe water stress for more of the growing season. Kaolin treatments did not reduce water stress in plants at the end of the growing season in September (Fig. 1a). At this point, the plants have already set fruit, which continue to ripen and the temperatures are often cooler than the preceding three months. This suggests that these late applications may not be as important for decreasing plant stress. Additional research should help answer these questions about timing of applications of kaolin.

\section{Literature Cited}

Baradas, M.W, B.L. Blad, and N.J. Rosenberg. 1976. Reflectant induced modification of soybean canopy radiation balance V. Longwave radiation balance. Agron. J. 68:848-852.

Basnizki, J. and M. Evanari. 1975. The influence of a reflectant on leaf temperature and development of the globe artichoke (Cynara scolymus L.). J. Amer. Soc. Hort. Sci. 100:109-112.

Bennett, C.W. 1971. The curly top disease of sugarbeet and other plants. Amer. Phytopathol. Soc. Monogr. 7.

Cottrell, T.E., B.W. Wood, and C.C. Reilly. 2002. Particle film affects black pecan aphid (Homoptera: Aphididae) on pecan. J. Econ. Entomol. 95:782-788.

Creamer, R., J. Carpenter, and J. Rascon. 2003. Incidence of the beet leafhopper, Circulifer tenellus (Homoptera: Cicadellidae) in New Mexico chile. S.W. Entomol 28:177-182.

Datt, B. 1998. Remote sensing of chlorophyll a, chlorophyll b, chlorophyll $\mathrm{a}+\mathrm{b}$, and total carotenoid content in Eucalyptus leaves. Remote Sensing Environ. 66:111-121.
Douglass, J.R. and W.C. Cook. 1952. The beet leafhopper. USDA Yrbk. 1952:544-550.

Gamon, J.A. and H. Qiu. 1999. Ecological applications of remote sensing at multiple scales, p. 805-846. In: F.I Pugnaire and F. Valladares (eds.). Handbook of functional plant ecology. Marcel Dekker, New York.

Gamon, J.A., C.B. Field, W. Bilger, O. Bjorkma,A.L. Fredeen, and J. Penuelas. 1990. Remote sensing of the xanthophyll cycle and chlorophyll fluorescence in sunflower leaves and canopies. Oecologia, 85:1-7.

Gitelson,A.A. and M.N. Merzlyak. 1994. Spectral reflectance changes associate with autumn senescence of Aesculus hippocastanum L. and Acer plataniodes L. leaves: Spectral features and relation to chlorophyll estimation. J. Plant Physiol. 143:286-292.

Gitelson, A.A. and M.N. Merzlyak. 1996. Signature analysis of leaf reflectance spectra: Algorithm development for remote sensing of chlorophyll. J. Plant Physiol. 148:494-500.

Gitelson, A.A., M.N. Merzlyak, and H.K. Lichtenthaler. 1996. Detection of red edge position and chlorophyll content by reflectance measurements near $700 \mathrm{~nm}$. J. Plant Physiol. 148:501-508.

Glenn, D.M.,E.Prado,A. Erez, J. McFerson, and G.J. Puterka 2002. A reflective, processed-kaolin particle film affects fruit temperature, radiation reflection, and solar injury in apple. J. Amer. Soc. Hort. Sci. 127:188-193.

Glenn, D.M., G.J. Puterka, T. Vanderzwet, R.E. Byers, and C. Feldhake. 1999. Hydrophobic particle films: a new paradigm for suppression of arthropod pests and plant diseases. J. Econ. Entomol. 92:759-771.

Han, J.-S. 1990. Use of antitranspirant epidermal coatings for plant protection in China. Plant Dis. 74:263-266.

Hunt, E.R. and B.N. Rock. 1989. Detection of changes in leaf water content using near-and middle-infrared reflectances. Remote Sensing Environ. 30:43-54.

Jifon, J.L. and J.P. Syvertsen. 2003. Kaolin particle film applications can increase photosynthesis and water use efficiency of 'Ruby Red' grapefruit leaves. J.Amer. Soc. Hort. Sci. 128:107-112.

Kamp, M. 1985. Control of Erysiphe cichoracearum on Zinnia elegans, with a polymer-based antitranspirant. HortScience 20:879-881.

Liang, G. and T.-X Liu. 2002. Repellency of a kaolin particle film, Surround, and a mineral oil, Sunspray Oil, to silverleaf whitefly (Homoptera: Aleyrodidae) on melon in the laboratory. J. Econ. Entomol. 95:317-324.

Lipton, W.J. and F. Matoba. 1971. Whitewashing to prevent sunburn of 'Crenshaw' melons. HortScience 6:343-345.

Ma, B.L., M.J. Morrison, and L.M. Dwyer. 1996. Canopy light reflectance and field greenness to assess nitrogen fertilization and yield of maize. Agron. J. 88:915-920.

Marco, S. 1993. Incidence of nonpersistently transmitted viruses of pepper sprayed with whitewash, oil, and insecticide, alone or combined. Plant Dis. 77:1119-1122.

Moreshet, S., Y. Cohen, and M. Fuchs. 1979. Effect of increasing foliage reflectance on yield, growth, and physiological behavior of a dryland cotton crop. Crop Sci. 19:863-868.

Penuelas, J., J. Llusia, J. Pinol, and I. Filella. 1997a. Photochemical reflectance index and leaf photosynthetic radiation-use-efficiency assessment in Mediterranean trees. Intl. J. Remote Sensing 18:2863-2868.

Penuelas, J., J. Pinol, R. Ogaya, and I. Filella. 1997b. Estimation of plant water concentration by the reflectance water index WI $\left(\mathrm{R}_{900} / \mathrm{R}_{970}\right)$. Intl. J. Remote Sensing 18:2869-2875.

Puterka, G.J., D.M. Glenn, D.G. Sekutowski, T.R. Unruh, and S. K. Jones. 2000. Progress toward liquid formulations of particle films for insect and disease control in pear. Environ. Entomol. 29:329-339.

Romney, V.E. 1943. The beet leafhopper and its control on beets grown for seed in Arizona and New Mexico. USDA Tech. Bul. 855 .

Schon, M.K. 1993. Effects of foliar antitranspirant or calcium nitrate applications on yield and blossom-end rot occurrence in greenhouse-grown peppers. J. Plant Nutrit. 16:1137-1149.

Showler, A.T. 2002. Effects of kaolin-based particle film application on boll weevil (Coleoptera: Curculionidae) injury to cotton. J. Econ. Entomol. 95:754-762.

Tworkoski, T.J., D.M. Glen, and G.J.Puterka. 2002. Response of bean to applications of hydrophobic mineral particles. Can. J. Plant Sci. 82:217-219.

Ziv, O. and R.A. Frederiksen. 1986. The effect of film-forming anti-transpirants on leaf rust and powdery mildew incidence on wheat. Plant Pathol. 36:242-245. 